\title{
RALAHINE: AN IRISH OWENITE COMMUNITY (1831-1833)*
}

SUMmary: This article is a study of the Owenite community established in Co. Clare, Ireland from November 1831 to November 1833. It examines the role of economic crisis in Ireland in stimulating interest in Owenite solutions. It analyses the differing motivations of the various actors (landowner, Owenite reformer, the peasantry) in joining the venture. It examines the sources of the community's stability - economic, sociological, and cultural. It argues that the community was destroyed by the contradictory roles of its founder, Vandeleur, who was both owner and President. In the process a detailed description of the community is provided, covering matters such as institutional arrangements, the division of labour, wages and benefits, gender relationships, and religion.

\section{Introduction}

In the first half of the nineteenth century, the work of Robert Owen helped inspire experimental communities in Scotland, England, the USA and Ireland. In subsequent surveys and histories, the community established from November 1831 to November 1833 on the 618 acres at Ralahine in County Clare, Ireland, has tended to stand out as the most successful of these. Writing in 1891, Beatrice Potter - later Beatrice Webb - referred to Ralahine (pronounced Rah-la-heen) as "the one successful experiment in Co-operative communities". ${ }^{1}$ S. F. Markham, in his 1930 A History of Socialism, called Ralahine "a remarkable success". ${ }^{2}$ A. L. Morton described it as "the only community on Owenite lines which looked like being a success", ${ }^{3}$ whilst R. G. Garnett judged that "Ralahine was a most successful experiment in communal living and social equality". ${ }^{4}$ Ralahine has

* I would like to thank the following for their valuable comments on earlier drafts: John le Juen, Bob Eccleshall, Richard Jay, Mick Cox, Paul Bew, Liam Kennedy, Cormac Ó Gráda and Bill Stafford. I would also like to thank the four anonymous referees, and the Executive Editor and his Editorial Committee, for their very useful comments.

${ }^{1}$ B. Potter, The Co-operative Movement in Great Britain (Aldershot, 1987), p. 30.

2 S. F. Markham, A History of Socialism (London, 1930), p. 10.

3 A. L. Morton, The Life and Ideas of Robert Owen (London, 1969), p. 60.

4 R. G. Garnett, "Robert Owen and the Community Experiments", in S. Pollard and J. Salt (eds), Robert Owen: Prophet of the Poor (London, 1971), p. 52. Garnett has provided pioneering accounts of Ralahine in this work and in his Co-operation and the Owenite Socialist Communities in Britain, 1825-45 (Manchester, 1972), pp. 100-129. His bibliographies are invaluable. An earlier, short account of my own research was 
also been noted for the bizarre manner of its demise - gambled away in a Dublin club! As a result the temptation has been to see Ralahine as an internal success destroyed by external bad luck. However, the reality was more complex, and the terms "internal" and "external", "success" and "failure" have to be used with the greatest of care. ${ }^{5}$ In what follows, an attempt will be made to reconstruct the history of this remarkable community.

\section{Robert Owen in Ireland}

When Owen visited Ireland in the autumn of 1822 , he came as a celebrated philanthropist, the friend of the powerful and the wealthy. Although his views on religion caused some disquiet, he was still seen as the remarkable architect of enlightened management at New Lanark. The fact that he was visiting Ireland at that precise time was not a matter of chance. Ireland was experiencing one of its periodic rural crises - triggered, on this occasion, by the failure of the potato crop. Famine generated violence and fear. Owen was invited to Ireland by progressive landlords such as Lord Cloncurry to discuss and publicise his possible solution to this recurring problem. More generally, an anxious landlord class was prepared to listen to anyone who promised a non-revolutionary way out of its difficulties. After touring various parts of the island, Owen gave the first of a series of lectures in Dublin on the 18th March 1823. These lectures were eagerly awaited; Daniel O'Connell wrote to his wife: "Politics are grown quieter here [. . .] but we are all alive with Mr Owen's plan. There is to be a great meeting tomorrow. I will go there if I can and make a speech." The presence in the audience of nobility, gentry and clergy, and the fact that the meeting was chaired by the Lord Mayor of Dublin, was a testimony to Owen's fame, to his political respectability, and to the anxiety of landowners.

In this and subsequent addresses, Owen relentlessly pursued his idée fixe of environmental determinism. ${ }^{7}$ Ireland from this perspective was distinctive only in terms of its degree of ignorance and unhappiness. Through-

published as "Ralahine: Ireland's Lost Utopia", Communal Societies, 9 (1989), pp. 91104.

5 There is an interesting discussion of the concepts of "success" and "failure" in J. F. C. Harrison, Robert Owen and the Owenites in Britain and America: The Quest for the New Moral World (London, 1969), pp. 175-176. This book is a gold-mine for anyone interested in Owenism. An excellent recent addition to the literature is G. Claeys, Citizens and Saints: Politics and Anti-Politics in Early British Socialism (Cambridge, 1989).

${ }^{6}$ M. O'Connell (ed.), The Correspondence of Daniel O'Connell, 2 (Shannon, 1972), p. 462.

${ }^{7}$ R. Owen, Report of the Proceedings at the Several Public Meetings held in Dublin (Dublin, 1823), p. 9. 
out, Owen reassured his privileged audience that they were in no way responsible for the sickness, and would not be harmed by the cure. ${ }^{8}$ All of Irish society would benefit from vastly increased prosperity, social harmony and religious freedom. ${ }^{9}$ The way forward was to establish cooperative communities in which new individuals would be created through enlightened educational and work patterns. He outlined the type of housing required, how labour would be allocated, the form child rearing would take, eating arrangements, types of clothing etc., etc.

Owen made it clear that these communities were directed at the lower orders, who were to be the objects of the benevolence of his audience. There was no suggestion that the "better sort" were to become members. His remarks were predominantly couched in terms of seeking the best means of dealing with the poor. Careful listeners may have heard his references to the communities as an "intermediate stage of existence", and of bringing benefits to the working class in the "first place", plus his brief remarks on the problems of other classes, and gained some insight into his ultimate direction, though no unsettling timetable was included. He was also keen to stress that this was not a utopian or "visionary" proposal, for it was derived from the "science of the influence of circumstances" 10 which had been confirmed by "nearly thirty-five years of successful experience". ${ }^{11}$ Although hopeful of Government sponsorship, he proposed that in the meantime a society should be set up to finance Irish cooperation. "I will find persons accustomed to, and experienced in, the different departments of the proposed communities who will arrange and put in operation the practical parts of the plan, until natives of this island shall be trained to supersede them." 12

Owen's proposals came in for stern criticism from a number of quarters. The clergy present were especially critical, asserting that Owen's plans were utopian, subversive, irreligious and unnatural. One such cleric, a Rev. Dunne, spoke of the "sacred tie between landlord and tenant", of "the sacred sympathies of the word "home" " and concluded that "he would rather see the poor peasant mending the thatch of his cottage with straw than seeing him roaming through the wide and stuccoed apartment of $\mathrm{Mr}$ Owen's workhouse, or partaking of a common meal in a common hall". ${ }^{13} \mathrm{~A}$ number of those present, however, spoke warmly in Owen's defence, and a group of the sympathetic joined with Owen in establishing the Hibernian

8 Ibid., p. 3.

9 Ibid., p. 22.

${ }^{10}$ Ibid., p. 14.

${ }_{11}$ Ibid., p. 66.

${ }^{12}$ Ibid., p. 138.

13 Ibid., pp. 37-38. 
Philanthropic Society to promote communal experiments. One supporter was moved to poetry in the Freeman's Journal:

O! God-like, comprehensive mind!

Immortal honours wait

Thee, Owen! friend of human kind!

At once the good and great ${ }^{14}$

A more restrained response was that of O'Connell, who had tried to speak in favour of Owen. In a letter of 10 May 1823 he wrote: "I shall become a subscriber to Owen's Society. He may do some good and cannot do any harm" ${ }^{15}$ Others, such as General Browne and Lord Cloncurry, subscribed quite large sums of money to the new society (Browne $f 1,000$, Cloncurry $£ 500$ ). Later in the year, a Select Committee of the House of Commons dealing with the plight of the Irish poor called Owen as a witness and considered (and rejected) his plan. ${ }^{16}$

\section{John Scott Vandeleur}

Ralahine owed its existence to one member of Owen's Dublin audience who was most impressed - John Scott Vandeleur, a landowner from County Clare. His presence at Owen's meeting in the early 1820 s and his eventual experiment at Ralahine in the early 1830 s coincided with two peaks of rural unrest in Ireland. To a man like Vandeleur, Owen offered a vista of social peace and prosperity - a happy marriage of morality and self-interest. Owen promised a permanent, peaceful, healthy and contented workforce with high levels of productivity (as he claimed had occurred at New Lanark). To ask whether Vandeleur saw Ralahine as a business venture or a philanthropic act is to miss the point; no such distinction existed: profits and prophets were at one. John Finch, a self-made Liverpool iron merchant and sympathetic visitor to the Ralahine community, later recalled his impressions of Vandeleur's motivations:

the difficulty of obtaining good, experienced, steady labourers, or of getting labourers at all when most wanted in harvest (as many of them went over to England at that time); the trouble he had to manage his workmen, from their drunken and disorderly habits, and the state of insecurity and alarm in which men of property were at that time placed, owing to the extreme poverty and

${ }^{14}$ Freeman's Journal, 25 April 1823.

${ }^{15}$ O'Connell, Correspondence, p. 471.

16 "Report from the Select Committee on the Employment of the Poor in Ireland", Parliamentary Papers VI, 1823, p. 339. 
consequent discontent and turbulence of the people, were a constant source of annoyance both to himself and his family whilst the pity and commiseration he felt for the grievous sufferings of his poor families around him, made him extremely anxious to do something to relieve them, and if possible permanently to remove the causes of their misery. Under these feelings it was with great pleasure he attended the lectures delivered by Mr. Robert Owen, in Dublin[;] he had frequent interviews with him, and carefully read and studied his writings; the consequence was, he became a thorough convert to Mr. Owen's great principle $[\ldots]$ and he became fully convinced [...] that it was perfectly practicable to cultivate land [. . .] in such a manner as to secure better rents to landowners, more interest for capital, and ten times more and greater advantages and enjoyment to labourers than can possibly be obtained by any mode at present adopted $[\ldots]^{17}$

If Vandeleur did become fired with Owenism at this time, he proceeded at a fairly modest pace. It is certainly the case that on his return to Clare, he began, over the course of a number of years, to lay the foundations for what he saw as modern and enlightened work structures. He set about building a weaving factory, a flax scutching mill, and bleaching works to benefit from a nearby stream. He also set about establishing appropriate housing for the workforce. From the perspective of a local newspaper, Vandeleur was merely one of a number of Clare notables who were introducing manufacturing schemes to boost employment. ${ }^{18}$ Almost a decade was to elapse before the community was established, and only then with a major worsening of rural conditions. That all this proceeded at a relatively slow pace can be attributed, at least in part, to the opposition he encountered from two sources: his labourers who, like the English Luddites, had understandable fears about the effect of new machinery on their livelihood; and his family and some neighbours, who were worried about his novel schemes. There is also evidence, as we shall see, that existing lease-holders had to be dealt with before sufficient land was available. In short, in the words of Edward Craig, later secretary of the Ralahine community, "Mr Vandeleur [. . . ] made several attempts at improving the habits and condition of the people; but they [ . . ] all failed to realise his expectations". ${ }^{19}$ It took the outbreak of a new wave of rural violence at the start of 1830 to accelerate Vandeleur's efforts.

${ }^{17}$ J. Finch, "Ralahine: Letter II", The New Moral World, 7 April 1838. Finch wrote 15 letters on Ralahine.

${ }^{18}$ See The Ennis Chronicle and Clare Advertiser, 10 September 1825, also 25 January 1826.

${ }^{19}$ E. T. Craig, "Letter IV", The Star in the East, 15 September 1838. 


\section{Rural unrest}

Clare exploded into violence when the powder-keg of rural grievance was ignited by a change in the system of "conacre". Under conacre, people who owned or tenanted land would let it, for short fixed periods, in return for an annual rental. Such rents were often high, and failure to pay would entail loss of the use of the land. Not surprisingly, this system created (and reflected) precarious conditions of existence for the poor, and was hardly conducive to rural harmony. However, matters only began to reach dangerous levels at the start of the 1830s, when increasing numbers of owners and tenants ceased to let under conacre. This was part of the general change in traditional patterns which ensued as farmers and large landlords sought to cope with the problems of the post-Napoleonic War economy. Tenants were evicted, small holdings reduced, and tillage converted into grazing. It was therefore the removal of even the possibility of exploitation rather than exploitation itself which broke the camel's back. In his evidence before the Devon Commission (1844), Vandeleur's onetime neighbour and friend, James Molony, a landowner of Kiltanton, Co. Clare, had no doubts about the principal source of the rural violence: "I must say, for myself, the origin of agrarian outrages very much arises from the want of con-acre land [...] There have been no agrarian outrages since 1831 in this district, and then they originated in the want of con-acre land."20 These changes occurred, moreover, at a time when an increasing population stimulated land-hunger, when the vital element of the poor's diet, the potato, suffered one of its frequent failures, and when a sudden fall in the price of cereals depressed wages and accelerated evictions. As Craig put it: "the starving peasantry were clamorous for land, for employment, and for food". ${ }^{21}$ Old grievances and new privations thus combined to create major social unrest.

In Clare secret societies like the "Terry Alts" and "Lady Clare's Boys"

20 " Report from Her Majesty's Commissioners of Inquiry into the State of the Law and Practice in Respect to the Occupation of Land in Ireland", Parliamentary Papers XX, 1845 , p. 663 .

${ }^{21}$ E. T. Craig, An Irish Commune (Blackrock, 1983), p. 2. This is an abridged version of Craig's 1882 work The Irish Land and Labour Question Illustrated in the History of Ralahine and Co-operative Farming (London, Trübner). Craig published many accounts of Ralahine in his long lifetime - some short, some long, and with a number of inconsistencies over time. He wrote forty-seven, mostly autobiographical, letters, "Socialism in England", for the American Socialist between August 1877 and November 1878 (these are numbered one to forty-six - with two letters numbered IX). He was the major source for W. Pare's account of Ralahine Co-operative Agriculture (London, 1870). His first lengthy and systematic account of Ralahine is to be found in a series of letters written to the The Star in the East from August to December 1838. Some earlier memories can be found in the The New Moral World, 12 November, 17 December, 24 December 1836 and 4 February 1837. His published reports and sketches in fact date back to the time the community was functioning. 
called for a reversal of the new grazing approach and for higher wages and lower rents. They used a variety of means to promote their cause, from digging up the land of offenders to the maiming of animals, and from assault to killing. No class was exempt, those who owned or tenanted land suffered, as did estate stewards and those labourers and small-holders who were deemed to be wilfully benefiting from their neighbour's misfortune. Much of the county became destabilised. The County Clare section of the Irish Poor Inquiry (1836) is full of statements such as "this district has been very much disturbed in the year 1831", and "in 1831 and 1832 this was the most disturbed and lawless part of Ireland" and, more fully:

"It was disturbed in 1831; it was then the system of Terry-Altism appeared; the impossibility of getting land at any rent to grow potatoes thereon compelled the poor to go out at night and turn up the pasture land, though not intending at first to proceed further than the digging of land; their success in that proceeding, and the recollection of the hardships they laboured under from starvation, \&c., maddened them, and drove them on to the commission of other outrages, at which human nature should shudder. ${ }^{22}$

Neither the State nor the Catholic Church seemed able to cope. As one local correspondent put it in April 1831, the peasantry "defied the government, whose military display had little terror for starving men, while catholic priesthood had no moral control over discontented people made furious by famine". ${ }^{23}$

Ralahine was not exempt. The Clare Journal of 13 January 1831 reported a raid on one of Vandeleur's workers by the "Lady Clare Boys" (a secret society whose members disguised themselves as women): "On Sunday last, a number of men, dressed in women's clothes, came to the house of a man named Enright, herdsman to John Scott Vandeleur Esq., near Cahiracon, and plundered it of a blunderbuss; the family were at mass at the time". ${ }^{24}$

22 Supplement to Appendix (E). Reports of Commissioners for Inquiring into the Condition of the Poorer Classes in Ireland. Parliamentary Papers XI, 1836, pp. 154-163. A study of the events of 1830-1831 in the Clare parish of Clare Abbey and Killone can be found in J. Power "Terry Alt and Lady Clare", The Other Clare, 10 March 1986. Interesting material on the social structure of a parish in Clare can be found in Part 1 of S. Kierse, The Famine Years in the Parish of Killaloe 1845-1851 (Killaloe, 1984). There has also been a study of another Clare parish, Kilrush. This parish is also of interest because its leading family was a branch of the Vandeleur family. James T. McGuane in Kilrush from Olden Times (Inverin, 1984), thus provides useful material on both the first half of the nineteenth century in the county and on the early history of the Vandeleurs.

${ }^{23}$ Quoted in F. P. Enright "The Pre-Famine Worker in the Shannon/Newmarket Area", The Other Clare, 5 April 1981, p. 8.

${ }^{24}$ Quoted in D. Lees, Ralahine: Land War and the Co-operative (Dublin, 1981), p. 17. For local newspaper accounts of the unrest see The Clare Journal for early 1831, particularly: 31 January, 21, 24 and 28 February, 10, 28, and 31 March, 4, 11, 14, and 25 April. See also Power "Terry Alt and Lady Clare". 
The precise nature of the economic relationships obtaining at Ralahine and in its vicinity is difficult to determine from the scanty evidence. All we know with any degree of certainty is that the estate was worked by labourers overseen by a steward. During this period of rural unrest the steward, Daniel Hastings, was shot dead. The accounts given by Finch and Craig explain this event in terms of the unpleasant character of the steward, his "haughty and tyrannical manner". ${ }^{25}$ It was the case, not surprisingly, that there was a great deal of resentment towards stewards and, as we shall see, one of the attractions of the Ralahine community for its members was the abolition of this office. It is also possible that some of Vandeleur's early changes may have caused local resentment. He had a reputation as a "scientific farmer" or "improving landlord", a type particularly unpopular with the social groups most at risk from improvements - labourers and smallholders - the groups at the heart of the "Terry-Alt" response. The opposition to machinery has already been noted. It is also known that he relocated some of his tenants to consolidate his holdings. A Mr Molony (possibly James Molony of Kiltanton Co. Clare), speaking to the Cooperative Congress in 1832, claimed, on the basis of direct acquaintance, that "Mr Vandeleur had some years ago formed an idea of establishing a Society [ . . . ] as soon as he should have enough land out of lease for such a purpose" ${ }^{26}$ One visitor, William Pare, speaks of "the interference of the 'Terry Alts' and the strong antipathy of the peasantry generally to manufacturing industry". ${ }^{27}$ There is also the report of a talk Craig gave to an audience in Salford (3 June 1832) which states: "and for introducing the Threshing Machine it is believed Mr. Vandeleur's steward was shot [. . .]." 28

The thesis that Vandeleur was, in a sense, destabilising the local community might also help to explain the hostility which Edward Craig encountered on taking up his post - the locals seeing him as the new steward for Vandeleur's projects. The very fact that Vandeleur belatedly took on board Owen's suggestion that Irish reformers should seek the assistance of trained cooperators from outside Ireland - in the shape of Craig - perhaps reflects a desire for a professional to overcome his own mistakes. Certainly Ralahine became caught up in the general climate of violence and insurgency, with a number of its labourers becoming active "Terry Alts". Whatever the reason for the deterioration of conditions, the Vandeleur family fled from Ralahine to Limerick, leaving the family house under armed guard. Ac-

${ }^{25}$ Finch, "Letter II".

${ }^{20}$ The Crisis, 12 May 1832. Crisis, and National Co-operative Trades' Union Gazette, 1-2 (New York, 1968).

2) Pare, Co-operative Agriculture, p. 71.

28 The Lancashire and Yorkshire Co-operator, July 1832. (Collected volumes reprinted by Greenwood Reprint Corporation, Westport, Connecticut, 1970.) 
cording to Molony, as a result of the new situation, Vandeleur "was compelled to begin a year and a half earlier than he intended to have done" ${ }^{29}$ It was in this context of heightened tension that Vandeleur made approaches to Edward Craig.

\section{Setting up the community}

Edward Craig was born in Manchester in $1804 .^{30}$ Lancashire in the first half of the nineteenth century saw a great deal of labour activity - both experimentation and unrest. Craig was in many ways a product of this environment. As a boy, living with relatives in Lancaster, he was present at the trial and execution of Luddites. At the age of fifteen, back in Manchester, he witnessed the Peterloo massacre. He trained as a fustian cutter and became deeply involved in the growing cooperative movement. In 1830 he became President of the small Owenian Co-operative Society, and, in 1831, editor of the Lancashire Co-operator. His name and reputation were passed on to Vandeleur, who set his proposal before Craig in Manchester. Craig agreed to come to Ireland despite the warnings of friends and family objections (he lost a legacy as a result). He was conscious of the taunt "utopian" and of the previous collapses of Owenite ventures in Scotland and the USA, but, as he recalled later, felt very positive about the experiment:

I felt the force of the objections urged on the ground of the plan being impractical, Utopian and absurd [...] I fully appreciated the difficulties, but I had confidence that with prudence and perseverance they might be overcome. It was also urged as a reason for not undertaking the task that $\mathrm{Mr}$ Owen had failed in America, and Mr Abram Combe had fallen a martyr to his efforts at Orbiston, which had also failed.

These objections did not seem to me well-founded, nor have they since. ${ }^{31}$

This then was the energetic young man who, Vandeleur hoped, would help him introduce Owenism at Ralahine.

Owenism had a distinct tendency towards elitist social engineering. It distinguished between an ignorant majority in the grip of irrational circumstances, and an enlightened minority whose superior understanding would be the saving of the rest. Owen's whole approach was very much in terms of

29 The Crisis, 12 May 1832.

${ }^{30}$ For Craig see R. G. Garnett "E. T. Craig: Communitarian, Educator, Phrenologist", The Vocational Aspects of Secondary and Further Education, XV (1963), pp. 135-150. Also note 21.

${ }^{31}$ E. T. Craig, "Letter XXII", American Socialist, 14 February 1878. 
active science moulding passive ignorance. In the period we are concerned with this often took a class form with the call to the "better section" of society to bring rationality to the sunken masses. In the case of Ireland this approach readily reinforced a particularly jaundiced view of the Irish peasantry held both by many British observers and by the indigenous ruling classes. Some of this undoubtedly reflected the appalling living conditions of the Irish poor but there was also both ignorance of the true nature of peasant life and a highly subjective definition of "civilization" in these characterisations. We have already heard John Finch's views on the local peasantry (which were based on hearsay and extrapolation rather than on direct acquaintance with conditions before the experiment); elsewhere he opines: "They were miserably poor, grossly ignorant; they were drunken, idle, vicious, and, perhaps, some of them even murderers". ${ }^{32}$ A whole series of assumptions drawn from Temperance thinking, educational theory, sexual mores, aesthetic ideals, notions of hygiene and countless other (frequently ethnocentric) influences coloured the observations of these individuals.

All of these factors had important consequences for the way Ralahine was organised and, subsequently, conceptualised. Treating the latter first, Ralahine's success was deemed to stem from its organisational principles, in spite of rather than because of its human material. Most of the various visitors argued that if you could make human beings out of such degraded stock, then anything was possible. This both overestimated the degree of change effected in Ralahine and underestimated the pre-existing capacities of its members. These friends of Ralahine, it might even be argued, had a vested interest in indulging their prejudice against pre-Ralahine conditions so as to throw into greater relief the triumphs of the new system.

With respect to organisation, Craig undoubtedly shared many of these negative assumptions. He too saw himself bringing civilization to a backward people, and introduced a number of prohibitions (alcohol, tobacco, gambling) and checks into the organisation of the community; thereby, as he saw it, to save the people from themselves. However Craig's account of what actually happened in the experiment tends to belie these caricatures of the Irish peasant. Craig was not a slavish disciple of Owen. He had his own ideas, drew on other sources such as the Irish socialist William Thompson, the Brighton cooperator William King and the pseudo-science of phrenology, and modified and ignored Owen's strictures when he felt it necessary. He was also capable of a degree of empathy with the local population. On a number of occasions he himself explicitly and implicitly acknowledged the good sense of the people and in practice introduced a good deal of popular

32 Finch, "Letter II". 
decision-making. The result was a curious mixture of autocracy and democracy, and a most ambivalent attitude to the ordinary membership.

This comes out very strongly in Craig's account of his initial moves. He found a peasantry committed to its old ways and by no means enthusiastic about his reforms. In characteristic Owenite fashion he ascribes this failure to prefer the rational to the irrational to the power of a bad environment. $\mathrm{He}$ is, however, sufficiently sensitive to realise that the old ways represented both freedom and tradition for many and therefore undoubtedly possessed a rationale for them:

It was not easy to convince them of the advantages of united homes and combined social arrangements. The peasantry, although living in extreme wretchedness, from their irregular employment and small earnings, were strongly attached to their old customs and isolated miserable cabins, with their apparent freedom. But their poverty and necessitous circumstances still rendered them the slaves of ignorance, vicious habits, and inveterate prejudices. ${ }^{33}$

His stated response was impeccably Owenite: "Owing to the prejudices of the people, it was necessary to adopt arrangements so as to train them to the system". ${ }^{34}$ This, for Craig, meant that, given the state of the local population, full-blown socialism could not be achieved overnight. Full equality lay in the future - transitional arrangements had to make do with less. Initial conditions needed to be created within which "the members would become prepared for a higher social condition in the course of time". ${ }^{35}$

Phrenology was of crucial importance to Craig. Although he saw no incompatability between Owenism and phrenology, in later writings he did bemoan what he took to be Owen's indifference to the "science", and suggested that the resulting inadequate grasp of human nature lay behind some of Owen's failures. Craig's phrenological beliefs led him to argue, contra Vandeleur, that some people were unreformable. Thus he argued that the relatives of the dead steward combined physiological deficiencies (in a phrenological sense) with suspicions that the murderers were to become members of the new community. This, he maintained, was bound to make them extremely difficult to mould:

They were large headed men, at least in the basilar region, and I therefore anticipated some difficulty in their management. Mr Vandeleur, however, felt quite assured that, by altering the circumstances which surrounded these individuals, the motives which led to their implacable hatred of others, who were to become members, would be thereby removed; but this was expecting too much

${ }^{33}$ Craig, Irish Commune, p. 23.

34 Ibid., p. 24.

35 E. T. Craig, "Letter XXXIV", American Socialist, 9 May 1878. 
from the influence of improved arrangements. For they believed these persons were implicated in the murder of their relative. ${ }^{36}$

This philosophy guided Craig's actions during the lifetime of the community, and since all new applicants had to approach him first, he used it as a basis for excluding prospective members once the experiment was established:

The first consideration in the admissibility of a candidate was his capability and willingness to unite in the practical operations for the production of wealth; and next his acquired habits, and what was of still greater moment, his moral and intellectual capacity, phrenologically considered. If it was found, after an examination of the individual's character, that he was uncontrollably influenced by his lower feelings; if his moral dispositions, or intellectual powers, were not active enough to check their injurious manifestations, then the person so organized, was at once rejected, however well he might come recommended as a workman, for his skill or industry. ${ }^{37}$

Owen had made it quite clear in his Dublin speeches that he considered quite a large number of people to be necessary to commence a community (between 500 and 2000). Vandeleur and Craig started with 52! (7 married couples, 21 single men, 5 single women, and 12 youths and children). This only rose to 81 in the second year ( 35 male adults, 23 female adults, and 23 youths and children). Craig recalled that on security grounds the experiment was based upon Vandeleur's employees: "Owing to the state of excitement in the district, we were, from motives of personal safety, compelled to begin with those employed on the estate". ${ }^{38}$ Finch talks of the desperate plight of the initial group, and of Vandeleur's fears about the outcome of the experiment:

Mr Vandeleur called a meeting of those persons from among whom he wished to form the Society [...] [These consisted] of the very poorest persons in the neighbourhood, many of them his former workpeople, without cottage, no other employment than his, not a shilling of capital [ . . . His reason for choosing such was, that, should the experiment fail, none of them might hereafter have cause for reproaching him with having made their condition worse than it was before.$^{39}$

Thus the starting group was a small body with close ties to the Ralahine estate.

${ }^{36}$ E. T. Craig, "Letter VI", The Star in the East, 27 October 1838. For Craig on Owen on Phrenology see: E. T. Craig, "Letter IX" (the second - there are two letters designated IX), American Socialist, 1 November 1877, also Garnett, "E. T. Craig", p. 150.

${ }^{37}$ E. T. Craig, "Letter X", The Star in the East, 8 December 1838.

${ }^{38}$ Craig, Irish Commune, p. 25.

${ }^{39}$ J. Finch, "Ralahine: Letter III", The New Moral World, 14 April 1838. 
It is clear that there was very little solid support for the experiment. Even amongst those who were not unsympathetic there was a fear that the community would not last long, Craig noting "that they did not expect the society to hold together above six weeks or two months". ${ }^{40}$ There was the history of resentment to Vandeleur's mechanisation (and possibly to his other improvements). There were a range of divisions based on status, function, kith and kin, dramatised and reinforced by the murder of Hastings (religion was not a factor dividing the locals - Hastings was not a Protestant (contrary to what his name might suggest) nor an outsider; he was, like the surrounding population in general, a Catholic and a member of a local family). There was the suspicion that Craig was Hastings' replacement, there as Vandeleur's servant, and there for his own gain. There was the feared loss of the old free ways (including some reluctance to give up alcohol and tobacco). There was, amongst some, a sense of shame that they were entering a paupers' colony or workhouse: Craig reported that "some of them viewed their entering into the society [. . .] as a disgrace to their family, owing to an opinion abroad, that it was to be conducted upon a plan similar to the "Mendicity Houses", or refuges for the poor" 41 (in nearby Limerick a "House of Industry" (an early type of workhouse) had been established in the eighteenth century). There was, furthermore, apprehension as to who could and should be allowed membership.

There were also a number of specifically Irish factors. In particular, there was the historically-grounded suspicions of an Irish-speaking Catholic people against the English-speaking Protestants Vandeleur and Craig, the former a member of the Anglo-Irish Ascendancy, the latter an actual Sasanach ${ }^{42}$ It should not be forgotten, in this context, that the same Daniel O'Connell who had attended Owen's meeting in Dublin had been swept to victory as MP for County Clare in 1828, committed to Catholic Emancipation - an issue embodying deep national and religious feelings amongst the populace.

The experiment did, however, get off the ground. Hope and fear, power and authority, belief and disbelief can be discerned in the various accounts. Undoubtedly, one factor was the desperate economic position. When things are so bad, the new is less threatening. In a context of famine and unemployment the promise of secure food and employment must have been beguiling. Another factor was that it was the landlord who was proposing the scheme. Vandeleur, as a member of the Ascendancy gentry

* Craig, "Letter VI", The Star in the East.

${ }^{41}$ Ibid.

${ }^{42}$ The evidence suggests, however, that amongst the Irish speakers there were few, if any, monoglots. English was understood and, when necessary, spoken in the community. See: E. T.Craig, "Letter XXVI", American Socialist, 14 March 1878; "Census of Ireland - General Report", Parliamentary Papers, XXXI, 1856, p. 222. 
(and one-time High Sheriff of the county), had great economic, social and political power in the locality. He was, therefore, not a man to oppose lightly and, more positively, his support may have given the experiment a degree of legitimacy.

We have therefore a range of responses. Some may have thought that the project might work - though it is not possible to ascertain how many. Craig suggests that one social group was more sympathetic: "one or two of the tradesmen on the estate had more confidence in my intentions [. . .] I was forewarned by them of events which were likely to frustrate me. ${ }^{.43}$ (Though it was amongst this least opposed group that the opinion was expressed that the experiment would only last eight weeks at the most.) There was thus a spectrum of increasing scepticism. Molony, in his report to the Co-operative Congress, said of the starting group: "only one or two out of the whole consider[ed] that it would permanently succeed. At first the working class, generally speaking, were against it [. . .]". ${ }^{44}$ Ralahine, whatever else it was, was not an example of messianic enthusiasm. This can be seen in the circumstances surrounding the ballot which set up the society. Craig decided that a public ballot was the best way to clear the air, meet objections, and give the community legitimacy. Vandeleur's address to the assembled people reveals the overall context most graphically:

My Friends, - Before I give the rules for adoption I find it necessary to have each member submitted to the ordeal of the ballot, because I have reason to suppose that some persons of one class have an unkind feeling towards others of another class and are also opposed to the system. I could now, before the rules are adopted, or the agreement signed, turn out any or every person that I supposed was not cordially inclined to co-operate for the benefit of each and all. So that now the only terms on which I will allow the rules to be passed will be that each person on the list, according as they are alphabetically arranged, shall be balloted for, and if any person should unfortunately happen to be rejected by a majority of the persons voting, I must, however disagreeable to my feelings, dispense with the services of that individual; and I can not any longer suffer that person to continue in the establishment. I am aware that some strangers are here, but Mr Craig expresses a strong desire to be elected or rejected by ballot, as it would be more agreeable to him to be admitted by the general body than that you should have it to say that I forced him on you. Then, when the members are elected, we will adopt the rules and sign the agreement; and I trust that those who now oppose the society will find it their interest to carry the rules into effect. ${ }^{45}$

${ }^{43}$ E. T. Craig, "Letter XXIII", American Socialist, 21 February 1878.

44 The Crisis, 12 May 1832.

${ }^{45}$ Craig, Irish Commune, p. 26. 
Craig's account has everyone surviving the ballot; Finch mentions two rejections. Vandeleur himself did not undergo the ballot.

\section{Aims}

The peasantry were told that both they and Vandeleur would benefit from the new arrangements. Craig made it plain in the preamble to the agreement the tangible benefits Vandeleur expected from the experiment. This was a section candidly entitled "The Advantages Which The Proprietor Anticipated" and which was fully in line with Owen's claim that cooperation made good business sense. The "Advantages" were (1) higher rent for land; (2) better interest on capital; (3) punctual payment; (4) security on advances, and (5) safety of stock, machinery and capital. The sixth had a more social feel to it: "To effect these objects in accordance with the laws, and, at the same time, improve the condition of every member of the association". ${ }^{46}$ In the same preamble under the heading "Objects Of The Association" the benefits for the ordinary members were laid out: (1) acquiring a common capital; (2) security against poverty, illness and old age; (3) a more comfortable life; (4) mental and moral improvement, and (5) education for children. Craig believed that the system would harness private interest to the common good. He described cooperation as "a system where all are labouring capitalists, instead of capitalists and labourers as at present"; ${ }^{47}$ elsewhere he put it this way:

The advantages which united exertions possess over individual competition are such, that a vast amount of human life will be preserved, labour saved, and happiness increased in a thousandfold, by the general adoption of this principle. At the present, the production of wealth, and the accumulation of capital is the paramount object of the leading writers in Political Economy. The happiness of the producers forms but a very small item in their calculations. But united exertions, where the arts of production are well understood, and are combined with a just distribution, will increase both wealth and capital to a very considerable extent, and incalculably increase human happiness. ${ }^{48}$

Since, in reality, this required the initial financial support of an affluent landlord, Craig's propaganda stressed both sides of the deal, as in the title he gave to one of his pamphlets: $A$ Remedy for the Pacification of Ireland or, How to Manage the Agricultural Population, and At the Same Time Secure a Good Rental, and Make a Prosperous, Contented, and Happy People. ${ }^{49}$

46 Ibid., p. 25.

${ }^{47}$ E. T. Craig, "Letter VI", American Socialist, 4 October 1877.

48 E. T. Craig, "Letter IX", The Star in the East, 17 November 1838.

4 E. T. Craig, A Remedy for the Pacification of Ireland or, How to Manage the Agricul- 
It is worth pausing here to consider the arrangement with respect to Vandeleur. The first thing to be noted is that Vandeleur rented the land, implements and stock to the community. The community had to accumulate sufficient capital beyond the rent to ultimately buy Vandeleur out. In the meantime, Vandeleur retained ownership. Owen considered this type of arrangement entirely legitimate and Finch, in this particular case, called it "common prudence, and justice to his family". ${ }^{50}$ Secondly however, as Cormac $O$ Gráda has shown, the rent was distinctly high by Irish standards. ${ }^{51}$ Vandeleur asked for $£ 900$ per annum (to be paid in produce). This figure was a source of resentment in the community. Craig noted: "One or two members thought the bargain somewhat too favourable for the landlord [. . . ] Had the rent been $£ 100$ less it would have made a vast improvement in the condition of the members [ . . ] The landlord admitted that the rent was too high". ${ }^{52}$ Thirdly, the ordinary members would initially only receive a wage (comparable with local norms). Profits were to be retained to buy the community from Vandeleur. This further safeguarded Vandeleur's position. Finally, if the community failed to prosper, everything would immediately revert to Vandeleur. Thus whilst reiterating the point that Vandeleur saw a harmony between doing good and doing well, he undoubtedly struck a hard bargain under very secure conditions for himself.

\section{Institutions}

Vandeleur had a dual role in the community. He was, as we have seen, the "external" backer. He also had the key central institutional role as an actual member. His powers were great and unrivalled:

(1) He had an absolute veto on new membership.

(2) He was the president of the society.

(3) He was president of the body that had day-to-day control of the community - the committee.

(4) He appointed the major office-holders, namely the secretary, treasurer, and storekeeper. The secretary and treasurer were, moreover, permanent members of the committee. His power was increased in this area by the fact that he paid part of the salaries of all three (the society paying the rest). It was certainly the opinion of Finch that these three

tural Population, and At the Same Time Secure a Good Rental, and Make a Prosperous, Contented, and Happy People (London, n.d.).

so Finch, "Letter III".

${ }^{51}$ Cormac Ó Gráda, "The Owenite Community at Ralahine, County Clare, 1831-33: A Reassessment", in Craig, Irish Commune, pp. 199-200.

${ }^{52}$ Craig, Irish Commune, p. 50. 
were Vandeleur's "servants, chosen by himself, and removable at his pleasure". ${ }^{53}$

(5) For the first twelve months he had the power to get rid of anyone misbehaving.

What this meant in practice is more difficult to determine. To Finch, regal and paternal images suggested themselves: "He presided at the meeting of the Society as king and father of his people" ${ }^{54} \mathrm{He}$ undoubtedly was able to steer the community in the direction he favoured, but this was achieved through rather indirect ways. Examples of his actual intervention are few and far between, and not of immense importance. There was, for example, a point where he introduced a rather unsuitable candidate into the community - one who eventually left. As Finch noted: "King Vandeleur had a power which we would by no means entrust to the governor of a community [. . . This power made him an absolute monarch, but he never used it".55

The real problem was Vandeleur's position as both proprietor and president. What was the role of an affluent landowner in a poor peasant's cooperative? The silence of the rules as to what Vandeleur's position would be after he had been bought out is a testimony to this ambiguity. Above all there was the possibility of conflict between his two functions. Certainly, to anticipate, the sad collapse of the community might have been avoided in the form it took, if a genuinely independent president had been able to obtain from Vandeleur a more solid legal status for the association. The danger throughout was that Vandeleur's private interests might lead the association in the wrong direction. But the limits to this counterfactual approach are clear, for Vandeleur's formal powers merely acknowledged his actual power and authority rather than creating them. It was these attributes of Vandeleur which set the agenda. Thus it was his existing relationship with Craig, rather than his formal power over the secretary which was important. Again in the case of the committee, it was their perception of his wishes rather than his actual presence (he was often absent) which was crucial. This is reinforced, if the account of William Pare (who visited Ralahine in 1833) is to be believed, by the fact that Vandeleur appointed the very first committee himself. ${ }^{56}$ Vandeleur would have remained a hugely powerful figure even if there had been an independent president. In this context therefore, it is even difficult to imagine different arrangements occurring. The net effect of all this was that the community contained a fatal structural flaw. It was dependent upon, and effectively

${ }^{53}$ J. Finch, "Ralahine: Letter IV", The New Moral World, 21 April 1838.

\$s Ibid.

${ }^{55}$ J. Finch, "Ralahine: Letter XIV”, The New Moral World, 1 September 1838.

s6 Pare, Co-operative Agriculture, p. 51. 
governed by, an individual whose interests did not entirely coincide with its own and over whom it had very little control. In this sense, the argument that Ralahine did not collapse for internal reasons is false. The external calamity which befell it was ultimately made possible by its internal structure.

This then was the framework within which the democratic aspects of the experiment functioned. Owen was highly suspicious of democracy. His world view predisposed him to favour scientific leadership. Committees should be dominated by the able. This was to be achieved by various devices, such as restricting committee membership to mature age groups and reserving a majority of committee places for the wealthy. In Ralahine there were two main democratic institutions: the committee and the general meeting. The rule dealing with the committee was as follows:

The society to be governed and its business transacted by a committee of nine members, to be chosen half-yearly, by ballot, by all the adult male and female members; the ballot lists to contain at least four of the last committee. ${ }^{57}$

The rule is rather confusing. If the first part is taken literally then the nine must have included the permanent members, Vandeleur, the secretary and the treasurer (rules 6 and 7). If this was the case then the second part of the rule is misleading because the above three could not be balloted for (Vandeleur as president chose the secretary and treasurer). If, however, the second part of the rule is taken literally, then this would have given a committee of twelve, not nine (with three ex officio members). On balance, it seems likely that the committee did consist of nine members. In a letter to William Pare, just prior to the formal commencement of the experiment, Vandeleur wrote: "the whole will be managed by a committee of nine. Consisting of a Chairman, (myself,) a Treasurer, a Secretary, (Mr. Craig, of Manchester,) three for agriculture, and three for trades and manufactures". ${ }^{58}$ Possibly the third part of the rule (the overlap of four members) was a way round the problem in practice.

The committee had a number of important functions. With respect to the organisation of work, it met every evening to decide who would do what the next day. It was also the body which received complaints of various sorts from the members. In an intriguing statement made in 1888, Craig described his role in the committee as "helping [. . .] but never voting". 59 Surfacing in this remark is both the fear of being too intrusive, and thereby undermining the young democracy, and a hint of distancing paternalism -

${ }^{57}$ Craig, Irish Commune, p. 40.

${ }^{58}$ Vandeleur to Pare, 3 October 1831. Printed in The Lancashire and Yorkshire Cooperator, 15 October 1831.

59 The Co-operative News, 7 January 1888. 
where formal democracy is seen as the sphere of the ordinary members, a sphere in which the guiding, Owenite intellectual need not, and therefore should not, participate. The committee had to account for itself to weekly general meetings of the adult members, and to a major half-yearly general meeting. This was not however a system of instant recall - members had to wait till the next ballot to change their representatives and could not, of course, remove Vandeleur and his two officers. Craig also introduced a "suggestion book" to increase the element of popular participation.

A general meeting could also change the rules of the community so long as three quarters of the members agreed. However, a number of matters were expressly exempted from this right. The agreement with Vandeleur could not be altered, nor could the institutional arrangements for expelling recalcitrants. The other exemptions reflect the particular crusades of Craig - the rules banning alcohol, tobacco, and gambling could not be changed or removed. Membership and expulsion had a democratic dimension. Anyone nominated for membership had ultimately to be balloted for by the whole membership (though they had to be initially vetted by Craig and could still fall foul of Vandeleur's veto on new members!). Similarly if a member married outside the community, the new partner had to undergo the ballot, and if rejected both partners had to leave the community. This did happen when the community rejected the new husband of the infant-school mistress. Finally (apart from Vandeleur's extraordinary 12 months' power to expel), the membership as a whole had the ultimate power of expulsion. The feeling one gets is that in practice the democratic element was confined to membership business and to matters of detail, rather than dealing with major policy decisions. None of the accounts give a single example of the latter. More typical, one suspects, is Pare's observation that "once or twice there were expressions of dissatisfaction at improvements being carried on, instead of purely tillage operations", to which he immediately adds: "but the behests of the committee were ordinarily cheerfully carried out". ${ }^{60}$

\section{Organization of labour}

The basic principles behind the new division of labour was that work should be determined by the community in the interest of the community. Negatively, this was seen as a rejection of the old system of steward organization and landlord appropriation. Craig sums up the philosophy behind this:

Formerly they were despised by the steward, and treated with indifference [. . .] They received their orders and performed as little work as they could for the

60 Pare, Co-operative Agriculture, p. 59. 
small return they obtained for their labour. In the new arrangements, every member felt he had an interest in preserving the property and increasing the produce. $^{61}$

Under the new arrangements, the office of steward was abolished. The committee decided labour patterns each evening, and its decisions were communicated to the membership via slates in the dining hall, each member being identified by a particular number. The daily employment patterns reflected overall strategies, the above-mentioned "suggestions" and, presumably, rule 15 of the association "that no member be expected to perform any service or work but such as is agreeable to his or her feelings, or they are able to perform". ${ }^{2}$ This latter element can be seen to some extent as a nod in the direction of qualitative theories of labour more explicitly developed in the Fourierist tradition. The daily decisions cannot, however, be seen as reflecting a Fourierist concern with the "Butterfly" passion for labour variation. The shifting needs of agricultural life, the imperatives of weather, growing seasons, etc., were the principal determinants on any functional changes that occurred from day to day (though one might interpret the rule that boys and girls should learn a useful trade as well as agriculture and gardening - an idea drawn from Owen - as partly reflecting a concern with all-round development). One further factor did enter the calculations of the committee however, and concerned that perennial problem of cooperative ventures: the freeloader. According to Finch, the committee organised labour so as to bring public opinion to bear on shirkers (for persistent malingering there was, of course, the ultimate sanction of expulsion).

They had at first two or three fellows inclined to be idle and they were cured in the way wild elephants are tamed. The committee who fixed the labour knew their characters, and appointed one of these idlers to work between two others that were industrious - (at digging for instance) he was obliged to keep up with them or he became the subject of laughter and ridicule to the whole society ${ }^{63}$

Age and gender played a part in the division of labour. Under the section of the rules entitled "Distribution And Domestic Economy", rule 16 states "that all services usually performed by servants be performed by the youth of both sexes under the age of seventeen years, either by rotation, or choice" ${ }^{64}$ This was unpaid labour. When it came to adult domestic work, there is evidence that this was done exclusively by women. In Dublin Owen had certainly favoured a conventional sexual division of labour:

${ }^{61}$ Craig, Irish Commune, p. 31.

${ }^{62}$ Ibid., p. 36.

63 J. Finch, "Ralahine: Letter X", The New Moral World, 30 June 1838.

64 Craig, Irish Commune, p. 36. 
That the employments of the female part of the community consist, in preparing food and clothing - in the care of the dwelling houses, dormitories, and public buildings - in the management of the washing and drying-houses - in the education (in part) of the children, and other occupations suited to the female character. ${ }^{65}$

Evidence from Ralahine can be found in a sample labour sheet quoted by Craig. Adult domestic labour in the community was of two kinds - paid work for the entire community (e.g., the communal laundry) and unpaid family tasks. The labour sheets recorded paid work and are divided into the functional branches of farm, family (i.e. paid domestic labour), and improvements. There are two names under the family heading. One is Anne Davine (sub-division "dormitories"), the other "C.E." (sub-division "washing"). Since, as we shall see, women were paid less than men at Ralahine, "C.E." was paid the same lower rate as Anne Davine which suggests that she was a women also. ${ }^{66}$ Also Finch noted: "One adult female had the charge of and kept the dormitories in order, and another female attended to the committee, lecture and dining rooms". ${ }^{67}$ In the case of unpaid domestic labour the rules of the Infant School demand "each child to be brought by its mother to the school at six o'clock in the morning, thoroughly cleaned, combed, and washed", ${ }^{68}$ and when for some reason the school was closed Craig recalled that the mothers had to stay at home to look after the children.

Ralahine departed from Owen's strictures on the sexual division of labour in two respects. First of all, women were not confined to domestic work exclusively. Besides unpaid domestic work, they were expected to engage in either paid domestic work or paid work of other kinds; thus labour lists record a number of women engaged in agricultural labour. Secondly, communal cooking seems to have been an exception, with Craig stating that "one man and a young woman prepared the food required by the whole community". ${ }^{69}$ This might be due to the fact that the steaming of potatoes was mechanised and the operative is always described in the accounts as a man, possibly leaving the rest to the "young woman".

This brings us to one final aspect of the division of labour - the role of machinery. The Luddite phenomenon reveals the threat machinery posed to various sorts of workers in early industrialism. Vandeleur had for long been keen on mechanisation, and, as we have seen, his early attempts had antagonised the peasantry. He clearly did feel that, given the small work-

${ }^{65}$ Owen, Report, p. 87.

${ }^{66}$ Craig, Irish Commune, p. 60.

${ }^{67}$ J. Finch, "Ralahine: Letter VIII", The New Moral World, 19 May 1838.

68 Craig, Irish Commune, p. 41.

69 Ibid., p. 115. 
force, agricultural machines were required. A correspondent of the Times who visited the community was even of the opinion that " 60 or 70 men and women cannot be expected to till 600 acres properly, even with the aid of improved ploughs, carts, a thrashing mill, \&c" ${ }^{70}$ In the reformed Ralahine, the climate had so changed that it witnessed the first successful introduction of a reaping machine in Ireland, a similar machine having recently been destroyed by a fearful peasantry in another part of Ireland. In a statement issued at the time, Vandeleur articulated labourers' fears about mechanisation in a competitive economy, and made the point that these were groundless in a cooperative venture: "Any kind of machinery used for shortening labour - except used in a co-operative society like ours - must tend to lessen wages, and to deprive working men of employment". ${ }^{71}$ The evidence suggests that agricultural mechanisation was popular in the community once the economic threat was removed. Another visitor " $S$ ", who was in Ralahine when the machine was introduced, wrote later:

these happy people welcomed the labour-saving machine as their best friend, with music and colours [ . . . The machine was invented and made by Mr. Mann, of Kelso, Scotland. The mechanic employed by the Ralahine Society, was sent over to Scotland to watch the progress of the works, and to accompany the machine to its destination [. . ]. The Members [ . . . had no fears. ${ }^{72}$

It seems clear that Vandeleur saw mechanised manufacturing as the vital component in the future prosperity of the community. John Finch recalled, in a letter of 1841 , that he had discussed the community's prospects with both Vandeleur and Robert Owen on his visit to the experiment. $\mathrm{He}$ suggests that mechanisation plans were well advanced prior to the collapse:

Mr Vandeleur and the society were about to prepare machinery for the factories [. . .] for the manufacture of such woolen, and other cloths, as are generally used in that part of Ireland. The works would have required a large number of additional hands, spinners and weavers, who would have consumed the remainder of the produce of the estate on the spot, and saved the labour and expense of taking this produce twelve miles to market, and the society would not only have been enabled to clothe themselves, but also to pay their rent and interest of money out of their own manufactures. ${ }^{73}$

In time, sufficient prosperity would be achieved to allow the society to buy Vandeleur out.

70 Printed in The Lancashire and Yorkshire Co-operator, March 1832.

${ }^{7}$ Craig, Irish Commune, p. 90.

7 The New Moral World, 28 May 1836.

73 The New Moral World, 27 March 1841. 


\section{Wages and benefits}

Payment at Ralahine was dependent on labour, or as Craig put it "If no work, no record, and therefore no pay". ${ }^{74}$ Correct returns were presumably based on a mixture of committee-members' "supervision", trust, and community pressure. Remuneration was not equal. Men received eightpence a day, women fivepence. Planned wage increases would have increased this gap by raising men's wages to tenpence a day but only raising women's wages to sixpence per day. ${ }^{75}$ None of the existing visitors' commentaries express any surprise or reservations about this - it is stated without comment. The silence drew to some extent on prevailing gender assumptions, but since the main commentators were committed to women's equality, this could not be the whole story. What one does sense is a series of "implicit" justifications in, for example, Finch's remark that women's paid labour was "easier", ${ }^{76}$ also in the reported lower expenditure on food by women, and in comparisons with the old system where, it was claimed, women received no wages and were totally dependent on men (i.e. a vast improvement is equity). Finch quite confidently opined that "in all respects females were upon terms of equality with males"77 (the existence of equal voting rights was remarkable for the time!).

Other differentials existed also. Some, like the gender difference, are reported but without explanation, for example, the secretary's wage of twice the labouring norm. Others are explained in terms of market realities: Vandeleur found that the only way he could attract various skilled workers was to pay them more than the average labouring member; thus whereas a labouring male received four shillings per week, and a female proportionally less, the carpenter received eight shillings and the carpenter's assistant six shillings (one wonders whether these were the "tradesmen" who first assisted Craig?). Payment was not in cash but in special labour notes. These notes, which came out of mainstream Owenism, were in various denominations and could be exchanged for goods at the community store or, in special circumstances, for cash. Craig recalled that at first "there was some objection to them on the grounds that 'they were not money'. But [. . .] ultimately the notes were preferred to cash payments". ${ }^{78}$ In a report to the Co-operative Congress in April 1833, Craig revealed that some external sources accepted the notes: they "are taken by a tailor, shoemaker, and hatter in the neighbourhood; could be tendered extensively in the localities

${ }^{74}$ Craig, Irish Commune, p. 74.

75 lbid., p. 44. This is also discussed in Lee, Ralahine, p. 38.

${ }^{76}$ J. Finch, "Ralahine: Letter XII”, The New Moral World, 14 July 1838.

$\pi$ Ibid.

${ }^{78}$ Craig, Irish Commune, p. 75. 
of Ralahine, if we thought it prudent to permit their extension" ${ }^{79}$ Craig was sufficiently impressed with these notes that he used the idea in a later educational experiment - Ealing Grove School. ${ }^{80}$

The community prided itself on its system of benefits. Free education for all children was one such benefit (in April 1833 there were nine such pupils $^{81}$ ). Education was at the very heart of Owenism. Create a beneficial environment when people are young and malleable, and superior adults will result. Craig had become involved in cooperation in the first place through an interest in Owen's educational experiments at New Lanark, and whilst preparing to move to Ralahine had written to Owen asking for "any suggestions, especially respecting the machinery of Infant Schools". ${ }^{82}$ At Ralahine the ideal was the communal rearing of children, with boys and girls sleeping in single-sex, communal dormitories. Financial incentives reinforced this with free food, clothing, etc., for the communal children and charges for those who remained in the family environment. A sick fund was established into which was paid one halfpenny out of every shilling received as wages (though Craig notes "There were no sick during the continuance of the society and this fund was discontinued"83). The children of any member who died came under the protection of the community. The elderly were also to be cared for. Under benefits one might also include the fixed, cheap prices of the various staples, particularly food. Finch claimed that wholesale prices cut the cost of many goods (presumably manufactured) by $50 \%$.

\section{Religion}

The founders of the community were very careful about the potentially explosive issue of religion. Two major pitfalls were avoided. Firstly, Owen's legendary hostility to religion tended to attract the label "atheist" to Owenism in general. In Scotland, both New Lanark and Orbiston became the targets for clerical ire and, as we have seen, the clergy pursued Owen on his Irish trip. Craig, although personally highly critical of the main faiths (he frequently uses the terms "prejudices" and "superstitions"), avoided any open attack on religion. This was partly a pragmatic response to the realities of the situation, and partly a rationalistic belief that prosperity and education would eventually bring the people to their senses. With studied indifference, religion was neither promoted nor condemned.

79 The Crisis, 13 July 1833.

${ }^{80}$ E. T. Craig, "Letter XI", The Star in the East, 15 December 1838.

81 The Crisis, 13 July 1833.

82 Garnett, Co-operation and the Owenite Socialist Communities, p. 107.

${ }^{83}$ Craig, Irish Commune, p. 38. 
A second and much more dangerous area was the question of the relationship between Protestantism and Catholicism. Apart from Edward and Mary Craig and Vandeleur and his family (and possibly one temporary English member, Joseph Cox) everyone in Ralahine was Catholic. The local people were hostile to Protestantism both as a religion and as an institution (tithes, state church, etc.). The situation had become tenser in the wake of intrusive proselytism by Protestant "missionary" societies. The sensitivity of the local people on the issue of religion was manifested when there was a change of teacher at the community school. Mrs O'Dea, the existing teacher (and a Catholic), left the community when her new husband was rejected in the ballot. When Mrs Craig took over, the parents withdrew their children fearing "that instruction would be given to the children contrary to the religious tenets of their parents". ${ }^{84}$ The school was forced to close. Peace was restored after a dignified letter from Mrs Craig (in which she denied any desire to change the beliefs of the children) was read to the general meeting, whereupon, "Mrs Craig was unanimously recalled to superintend the school". ${ }^{85}$ A whole range of measures were introduced to cope with the religious susceptibilities of the people. Finch recorded them:

the Bible was not used as a schoolbook; no sectarian opinions were taught in their schools; no public disputes about religious dogmas [ . . ] took place; nor were members allowed to ridicule or revile each other's religion; nor was there any attempt at proselytism. Perfect freedom in the performance of religious duties and religious exercises was guaranteed to all. The teaching of religion to the children was left to ministers of religion, and to the parents; but no priest or minister received anything from the funds of the society. ${ }^{86}$

The fact that the very influential local Catholic clergy gave their support to the community is a measure of the success of these strictures. The experience of Ralahine can be compared with the factious career of the community established by the Rev. Edward Nangle on Achill Island in County Mayo. This was created in the wake of the famine of 1831 and was dedicated both to promoting the material well-being of the local peasantry and converting them to Protestantism. This religious militancy provoked much local strife. The Catholic clergy waged war on it and established rival schools. In this increasingly sectarian atmosphere, verbal abuse eventually turned into violence ${ }^{87}$ Although Nangle's community lasted much longer

\$4 Ibid., p. 118.

${ }^{85}$ Ibid., p. 119.

${ }^{86}$ Ibid., p. 121.

${ }^{87}$ See I. Whelan, "Edward Nangle and the Achill Mission, 1834-1852", in R. Gillespie and G. Moran (eds), A Various Country: Essays in Mayo History 1500-1900 (Westport, 1987); also K. McNally, Achill (Newton Abbot, 1973), pp. $94 f$. 
than Ralahine it existed in a thoroughly poisoned environment. Ralahine, in contrast, was able to keep religious passions judiciously under control.

\section{The community in action}

For the ordinary member, daily life was spartan. The working day was long, from six in the morning till six in the evening in summer, and from daybreak till dusk in winter. One hour was allowed for dinner. A labour list for one day reveals the overwhelmingly manual nature of most work: 15 men spade cultivation, 4 men making up compost, 4 men carting manure, 4 men ploughing, 3 men attending cattle, 1 man steaming potatoes, 1 man butchering, 3 men at carpentry, 2 men smithing, 1 man keeping the store, 1 male secretary, 8 women at "agricultural operations", 3 women at dairy and poultry, 1 woman at domestic arrangements, 1 schoolmistress. ${ }^{88}$ As the list suggests, commercial manufacturing was absent from this essentially agricultural community. Although both Craig and Vandeleur looked forward to the day when this would be remedied, the most that was achieved was some small-scale production for internal consumption (Ralahine was, therefore, not self-sufficient).

The main crops were wheat, barley and oats, the principal vegetables, potatoes and turnips; pigs, sheep, cattle and horses were also kept. Food was, however, very basic. The crops and animals were predominantly commercial ventures reserved for (primarily) the payment of Vandeleur's rent and (if anything was left) the accumulation of capital and a small wage increase. The average daily diet was vegetables (mainly potatoes) and milk. A number of commentators gave ingenious glosses on this. Craig saw it as a healthy diet, partly responsible for the "easy confinements" and rapid recovery of local women, whilst Finch argued:

let those who find fault with the milk and vegetable diet of Ralahine reflect, that "no human being has any natural right to require another to do that for him or her that he or she would refuse to do for that individual;" and therefore, in a rational state of society, all those who will eat beef, mutton, veal, and pork, must in turn kill the animals for themselves. ${ }^{99}$

In reality the diet reflected the level of wages. The most economical way was to eat at the common table. People wishing to fend for themselves, or who desired extras, had to pay accordingly. Finch himself notes elsewhere: "those who received the higher wages had tea and coffee, and occasionally

${ }^{88}$ Craig, Irish Commune, p. 135.

${ }^{89}$ Finch, "Letter VIII". 
flesh meat". ${ }^{90}$ Men and women ate different quantities of food. Thus, for example, Finch records that men drank ten quarts of milk per week (cost 10 pence) whilst women drank eight quarts (cost 8 pence). Since he further records that men paid one shilling per week for vegetables and women sixpence this suggests different levels of intake rather than a discount for women (though some element of discount cannot be entirely ruled out given the fact that women paid less to the sick fund). Married couples lived in separate dwellings, for which they paid sixpence per week for rent and twopence per week for fuel. Everyone else lived in communal buildings. Leisure time, according to the accounts, included general meetings, adult education, and sober country dances. Vandeleur's family took no part in the experiment and lived the traditional life of the Anglo-Irish gentry.

For over two years the community undoubtedly functioned. It also seemed to have functioned satisfactorily for a variety of social groups. The problem is, of course, that we have no existing record of what the ordinary members actually thought as opposed to what they were supposed to have thought in the various accounts. Our measures have to acknowledge this important gap. The first measure we can apply is the fact that the community was able to meet Vandeleur's high rents and produce a surplus as well. Furthermore, new land was brought into cultivation and yields were increased. The ordinary members were also able to accumulate savings of up to several pounds each out of their wages (the community had its own Savings Bank ${ }^{91}$ ). It is tempting to speculate on what Ralahine's achievements might have been if this rent burden had not been present - Craig had no doubts: "It was very evident [. . .] that if the land had been the property of the members they would soon have become very prosperous and wealthy". ${ }^{92}$ Vandeleur certainly had nothing to reproach the community with. This reinforces the references, in the various accounts, to the hard work of the Ralahine peasantry. It also provides some evidence that a new spirit had emerged. The response of members of the community to a fox hunt can be seen as further evidence. In the winter of 1832, whilst Vandeleur was away, the local hunt chased a fox towards Ralahine:

the members in the farmyard closed the gates, and brought the huntsmen abruptly to bay, and thereby put a stop to the chase for the day. The horsemen were astonished at the presumption of the men of the "new system" who had thus dared to interfere with their sport [...] Many of the huntsmen loudly expressed their disappointment and indignation at the rudeness of the labourers daring to talk to them about "young crops" and "damaged fences!". ${ }^{93}$

90 J. Finch, "Ralahine: Letter VI", The New Moral World, 5 May 1838.

91 The Crisis, 13 July 1833.

92 Craig, Irish Commune, p. 50.

93 Ibid., p. 110. 
Another measure we might consider is the increase in applications to join the community from the local peasantry. Craig recalled that "we had numerous applications during the spring and summer of the second year of our operations. The social privileges of the members were found to be far greater than those of small farmers in the neighbourhood". ${ }^{24}$ Although "numerous" here means "tens", it is indicative of growing respect and popularity. Craig had no doubts as to the achievements of Ralahine. Like Owen at New Lanark, he had demonstrated, in far from ideal conditions and with therefore only partial application, that socialism was possible: "It is no longer a theory or Utopia, as in the days of Plato and More, but a real, tangible verity". .5

There is also the testimony of the various visitors, who not only spoke in glowing terms about the experiment but, in some cases, resolved to imitate it. Owen himself visited the community in 1833 and on his return described Vandeleur as "the only gentleman in Ireland who has made experiments on a large scale to try the effect of our principles". ${ }^{96} \mathrm{He}$ also replied to Craig's letter asking for his opinions thus:

It appeared to me, from a full inspection of your proceedings at Ralahine, that, considering the means which your association possessed, your arrangements to produce and distribute wealth, to educate and form the character of the people, and to govern them, were excellent and carried on in the true spirit of cooperation. The people appeared to me more happy than any of the same class in any part of Ireland, which at various times I have visited, and that the proprietor was not only in much greater security from injury of person and property, but he expressed to me in very strong terms the great satisfaction which he daily experienced from being with the co-operators, and witnessing the extraordinarily successful progress which you were making towards independence for yourselves and for him. ${ }^{\text {? }}$

We should be cautious about the various accounts and commentaries written by visitors and contemporaries. The fact that Owen called Vandeleur's efforts "large scale" should not blind us to the fact that the former always considered Ralahine to be only a partial implementation of his principles. Craig cuts from his book-length account the end of Owen's letter:

Until the Landowners, Capitalists, and Farmers shall discover the incalculable advantages which one and all would experience from the adoption of the full

94 Ibid., p. 135.

95 Ibid., p. 79.

96 The Crisis, 15 June 1833.

${ }^{97}$ Craig, Irish Commune, pp. 127-128. 
community system in principle and practice, I would strongly recommend them to commence the more limited plan adopted at Ralahine. ${ }^{98}$

There is also the problem of the rose-tinted spectacles worn by those visitors who came determined to be impressed. Furthermore, there is the problem of class definitions of success. Many of the accounts conceive of Ralahine as a way of coping with the poor i.e. keeping them quiet, functioning, and not actually starving. Lord Wallscourt, for example, who copied elements of the system, later wrote: "It answers much beyond my hopes, inasmuch as it completely identifies the workmen with the success of the farm, besides giving me full liberty to travel on the continent for a year at a time" ${ }^{99}$ Finch saw as a positive feature of a more widespread use of the Ralahine system that it would "destroy trades' unions, combinations among workmen, and political associations of all kind". ${ }^{100}$ There was also a perception of Ralahine as a solution to the "Irish Question". Treat the peasantry well, the argument went, and they will cease to support nationalist agitators.

Why was the community able to function? We have already discussed the complex motivations of the peasantry in joining the association, and these are themselves a major factor in the survival of Ralahine. One suspects, for example, that Vandeleur's power and authority retained their potency. In this respect the two "successes" of the Owenites, New Lanark and Ralahine, differ from the other experiments in that both built upon existing structures of power and authority. A nineteenth-century American critic of Owen's handling of New Harmony draws, albeit in a jaundiced and unfair manner, this distinction: "He found democrats harder to manage than the servile workmen of Scotland". 101

Once established, Ralahine gained strength from a number of sources. As we have seen, Craig was an able and conscientious organizer. Of particular note here was his introduction of proper accounting procedures which helped to save Ralahine from the financial chaos which, for example, beset the Owenite community of Queenwood. This was clearly helped by the financial backing provided by Vandeleur (till his fall) - again avoiding the undercapitalisation problems experienced by some of the other communities (e.g., Orbiston and Queenwood). However, this financial rectitude was itself greatly facilitated by the toughness of life, and the relatively modest nature of the experiment, at Ralahine.

9 Advertisement in The Star in the East, 15 December 1838.

* Craig, Irish Commune, p. 131.

100 J. Finch, "Ralahine: Letter XV", The New Moral World, 20 September 1838.

${ }^{101}$ L. R. Leonard quoted in G. B. Lockwood, The New Harmony Movement (1905) (New York, 1970), p. 184. 
In a number of different ways, the harsh living conditions of the Irish peasantry played a major role in the stability and durability of the community. Much of the success of Ralahine had to do with the previous experience of the ordinary members. Uncertainty was a major problem of the old ways, particularly uncertainty of labour and the linked uncertainties of wages and food. The provision of all-year labour at Ralahine must have been a major factor in its favour. Another factor was the regimen of hard physical labour which was the lot of the Irish peasant. This, in many respects, was a much more suitable human base for the difficult work of building a new agriculture-based community than less hardy urban types. The two members of the Ralahine community who left of their own accord were both non-manual workers. It was certainly Craig's opinion that the communities at Orbiston, New Harmony, Manea Fen, and Tytherly (Queenwood) made the error of "admitting persons indiscriminately, and before any trades had been fixed upon, in which it was ascertained their services would be required and become reproductive". In the same vein the very basic vegetables and milk diet of the peasantry, and their relatively spartan experience in relation to housing and consumer goods kept costs down and rendered conditions not merely bearable but desirable. Ralahine was thus able to match expectations with conditions, whereas at Orbiston, Craig argued, "consumption, recreation, and enjoyment, far exceeded the powers of production in the essentials of existence". ${ }^{103}$

The fact that the community was drawn from people sharing a common geographical, sociological and cultural background must also have been a powerful cementing factor. Unlike some communities (New Harmony, for example), this one was not drawn from heterogeneous settlers. In particular, Ralahine may have drawn strength from the complex pattern of rural solidarity and discipline evident in pre-Famine Ireland. The "Terry-Alt" phenomenon, for example, does seem to show both the existence of a widespread value system and the capacity of the rural community to punish those who violated these values. One should not, however, overestimate (and romanticise) the degree of cohesion and discipline. Economic hardship and sub-community loyalties such as kinship could cause deep social fissure ${ }^{104}$ (both Craig and Finch comment on the factional dimension in the local community). One final positive feature worth mentioning was, contra

102 E. T. Craig, "Letter X", American Socialist, 8 November 1877.

${ }_{103}$ The Co-operator, April 1864.

104 On this controversial topic see M. R. Beames, "Rural Conflict in Pre-Famine Ireland: Peasant Assassinations in Tipperary 1837-1847", Past and Present, 81 (November 1978), pp. 75-91, and D. Fitzpatrick, "Class, family and rural unrest in nineteenthcentury Ireland" in P. J. Drudy (ed.), Ireland: Land, Politics and People (Cambridge, 1982), pp. 37-75. 
Owen, the fact that Ralahine was a small grouping, thereby creating classically favourable conditions for cooperative and democratic structures. The size of the group also contributed to the financial viability of the experiment, for costs were both bearable and manageable. All these are part of the background to Ralahine's survival.

\section{Collapse}

Disaster arrived from right out of the blue. With a horrible irony it was gambling, banned at Ralahine, that destroyed the community. Vandeleur, as ever a law unto himself, lost far beyond his means in his Dublin club, tried fraudulently to get money from the bank to pay his debts, was discovered, and fled the country. He was declared both bankrupt and outlawed. To the member's horror it was found that the agreement between Vandeleur and the community was considered legally worthless. One final blow for Craig was that he considered himself personally liable for the accumulated labour notes of the members (worth f25), and therefore felt obliged to exchange them for cash out of his own resources. The estate was then sold and the community destroyed. Craig was bitter in his reminiscences:

The members were held to be common labourers, with no rights or claims for improvements, as all they had created and added to the estate belonged to the landlord and his creditors. Legally they were right. It was robbery nevertheless. We had paid our rent, but were remorselessly evicted. We had no remedy. Ruin came upon us suddenly, and Social Co-operation at Ralahine was at an end. ${ }^{105}$

The shock and the sadness still resonate in Craig's 1882 account, though almost half a century had elapsed:

The intelligence came upon our happy community like an unexpected thunderbolt [. . .]. I was much agitated and agonised, when, at intervals, the people would cry aloud from the depth of their sorrow, 'Ohone! ohone! Shahn Vandeleur, why did you go from us? Ohone! Vandeleur! why did you leave us? Why have you left your own Rahlaheen? [ . . ] I arose next morning with many grey hairs [ . . ] The recollection of these scenes, although whole oceans of events have intervened, makes the heart sad, and the feelings are awakened by the echoes of the past that now fall on the ear, and cause tears to flow and wet the paper on which I write. ${ }^{106}$

${ }^{105}$ Craig, Irish Commune, p. 160. For newspaper accounts of these events see: The Limerick Chronicle, 13 November 1833, The Dublin Evening Post, 21 November 1833, The Clare Journal, 10 March 1834, and The Clare Journal, 6 June 1834.

${ }^{106}$ Craig, Irish Commune, pp. 148-152. "Ohone" is a mistranscription of the word "Ochon" which means "Alas". David Lee gives the correct usage in Ralahine, p. 51. 
Vandeleur, according to family legends, ended up as a train driver in America. Craig left Ireland and returned to his involvement in English cooperation. The peasantry went back to the old ways. ${ }^{107}$

\section{Conclusion}

Would Ralahine have survived if Vandeleur hadn't gambled it away? Leaving to one side Ralahine's internal strengths and weaknesses, it had the immense problem of being a brave deed in a naughty world. As its eventual demise revealed, existing power structures showed little sympathy for the aspirations of ordinary working people - a problem compounded in Ireland by the vicissitudes of history. How it would have survived or grown over a much longer period in that sort of climate is not at all clear. It should be noted in this connection that the relations of William Thompson (who had himself visited, and been influenced by, Ralahine) contested his will partly

107 The ordinary members had to cope with the Great Famine of 1845-1849. County Clare was one of the four worst affected counties in 1845 (official figures, probably overestimated, suggest that in this initial year over $50 \%$ of Clare's potato crop was destroyed by the blight). Since the other three counties (Antrim, Monaghan, and Waterford) were relatively cushioned by their affluence, it could be argued that Clare suffered the first hammer-blow of the famine (see M. Daly, The Famine in Ireland (Dundalk, 1986) ). Up to this period the population had been rising. The difference between the censuses of 1841 and 1851 reveal the immediate impact of the Famine in terms of death and emigration (Rathlaheen North: 1841, 83 persons; 1851, 6 persons; Rathlaheen South: 1841,364 persons; 1851,337 persons). The figures toward the end of the century tell a story of continuing decline (Rathlaheen North: 1881, 1 person; Rathlaheen South: 1881, 33 persons). Sources: "Population (Ireland)", Parliamentary Papers, XCI, 1852-1853, p. 389; "Population - Census of Ireland", Parliamentary Papers, XCI, 1892, p. 24.

To obtain population figures from the 1821 and 1831 censuses one has to use the broader parish unit of Tomfinlough (which includes Ralahine and other local areas, including the town of Newmarket-on-Fergus). Again the effects of 1845-1849 are clear: 1821,$2789 ; 1831,4053 ; 1841,4401 ; 1851,3182 ; 1881,1726$. Sources: "Population Abstract of 1821", Parliamentary Papers, XXII, 1824, p. 138; "Population of Ireland", Parliamentary Papers, XXXIX, 1833, pp. 128-129; "Population - Census of Ireland", Parliamentary Papers, XCI, 1892, p. 24.

A degree of historical justice was, however, achieved. When the estate was broken up in the 1920s (as a result of the Land Act) a number of the new small farms passed into the ownership of direct descendants of Ralahine members. See: M. Enright, "Ralahine Clare's First Experiment in Socialism", The Clare People, September 1977, p. 13.

The story of Vandeleur's family is a sad one. Of his five children, three died as youngsters: Boyle, the eldest son, was drowned, whilst Diana and Emily died of tuberculosis; Arthur, after a distinguished military career, died at the age of 31 . Emily Vandeleur, John Scott's wife, never recovered from the shock and died in June 1843. Arthur, with the help of relatives was, however, ultimately able to keep the estate in the Vandeleur family. 
on the grounds that his intention to leave his Irish estate to his tenants for cooperative purposes was a clear sign of an unsound mind. One wonders how many of Ralahine's rich and powerful friends would have remained once the perception grew amongst them that the landlord-led response to economic and political crisis had turned into an independent Owenite cooperative? There was also the whole problem of productive relationships. Irish rural life was very precarious for those at the bottom. Barely fifteen years after the end of the experiment, a sequence of potato failures unleashed the Great Famine, which killed one million people and forced a million and a half to emigrate. Even before this, Cormac $O$ Gráda has speculated, "the experiment would have had difficulty in surviving the crisis of 1839-1840"108 if Vandeleur had demanded the same level of rent. Even if one assumes that a degree of mechanised production had been achieved, the terms of the agreement would have had to be substantially altered in favour of the ordinary members for the community to have survived in the ensuing years. This would have brought into sharp focus the intentions of Vandeleur and the strengths and weaknesses of the community. One would also expect moves towards redefinition of the arrangement in the wake of rising expectations. Since the stability of Ralahine owed much to the previously harsh conditions of its inhabitants, increasing prosperity would tend to put a large question-mark over the initial agreement. Again, this would have tested the strength of the experiment.

Ralahine has always been of more than antiquarian interest. Just as its conception and birth were deeply embedded in the political currents of the time, so too has its life and death become the raw material for subsequent political speculation. For much of the nineteenth century, Ralahine received comparatively little attention. New Lanark, Orbiston and New Harmony were much better known, both inside and outside the labour movement. John Finch's work was known, but it was through the tireless publicity efforts of Craig (in particular his 1882 book-length account) that Ralahine reached the world stage. From the 1880 s the community began to appear more frequently in books and articles. A number of Irish socialists saw in Ralahine (suitably stripped of landlord encumbrance) a glimpse of the future. One such, in the late nineteenth century, was the Rev. Bruce Wallace, who used Ralahine, "this splendid work", 109 to argue for land

108 O Gráda, “The Owenite Community", pp. 204-205. In an 1838 account, Craig suggests that just before the community collapsed Vandeleur was planning to ease the burden of the community: "Mr Vandeleur had made arrangements at the end of 1833 for reducing the terms, and making the profits resulting from the exertions of the people more certain and available than they were the first two years". E. T. Craig, "Letter VIII", The Star in the East, 10 November 1838. No details are given.

${ }^{109}$ B. Wallace, "E. T. Craig - The Pioneer of Ralahine", in M. O'Riordan (ed.), Ralahine (Dublin, 1985), p. 44. 
nationalisation against both peasant proprietorship and the existlng landlordism. At the beginning of this century, the Irish marxist James Connolly considered Ralahine to be the embryonic form of a new Ireland. He envisaged a nationwide system of worker-controlled enterprises - "the extension on a national basis of the social arrangements of Ralahine". ${ }^{110}$

Outside Ireland, Ralahine was referred to by other marxists. Kautsky, in The Agrarian Question (1899), quoted a lengthy account of the experiment and argued that Ralahine proved that workers could carry on large-scale collective farming (though he warned: "One cannot simply leap over a stage of development. Under normal circumstances, the vast bulk of ordinary folk cannot pass directly from the craft or peasant enterprise to the large-scale co-operative". ${ }^{111}$ ) In the same year Lenin cited Kautsky's discussion to make the identical point about Russia. ${ }^{112}$ Ralahine, in fact, figured in a number of people's discussions. In Russia, an 1899 edition of the liberal Narodnik journal Russkoye Bogatstvo carried an account of the community. ${ }^{113}$ In England, General William Booth, founder of the Salvation Army wrote in In Darkest England, and the Way Out (1890): "I shall endeavour to start a Co-operative Farm on the principles of Ralahine and base the whole of my Farm Colony on a Co-operative foundation". ${ }^{114}$ In an 1896 work, the German cooperative writer Franz Oppenheimer cited Ralahine (a "wonderful success") in his advocacy of internal cooperative colonisation, ${ }^{115}$ whilst 1902 saw the publication of a utopian novel Altneuland by the Zionist writer Theodor Herzl foreseeing "thousands of Ralahines" in Palestine. ${ }^{116}$

In trying to assess Ralahine it is difficult both to distinguish objective cause from subjective agency and to establish their relative causal power. Ralahine was neither a collection of free experimenting spirits nor the inexorable result of iron determinants. We have seen that many things made Ralahine possible. Rural crisis engendered a worried gentry and a desperate peasantry. Owen's visit was symptomatic of this fact. In turn, Owen provided a theory which flattered and promised to enrich reforming landowners. The balance of power and authority on the land enabled Vandeleur to commence his experiment. Once established, the community also drew on a whole range of sociological, economic, geographical, cultur-

110 J. Connolly, Labour in Irish History (Dublin, 1971), p. 89.

${ }^{111}$ K. Kautsky, The Agrarian Question, 1 (London, 1988), p. 131.

112 V. I. Lenin, Collected Works, 4 (Moscow, 1972), p. 121.

${ }^{113}$ Ibid.

114 Garnett, Co-operation and the Owenite Socialist Communities, p. 122.

${ }^{115}$ E. Hasselmann, "The Impact of Owen's Ideas on German Social and Co-operative Thought during the Nineteenth Century", in Pollard and Salt (eds), Robert Owen: Prophet of the Poor, p. 303.

116 T. Herzl, "Neudorf - A Ralahine in Galilee", in O'Riordan (ed.), Ralahine, p. 51. 
al and historical factors for stability. At each turn, however, different outcomes could have occurred and, in different locations, did. At every point an irreducible and ultimately decisive factor of subjectivity came into play. Ralahine was the meeting point of some very impressive individuals, Vandeleur, Craig, Craig's wife Mary, Mrs O'Dea and the largely unknown local population - Anne Davine, "Widow" Murphy, William Frawley, John Hogan, James Hastings, Michael McNamara, T. Carmody, T. Enright, "P.F.", "T.W.", etc., etc. These people made the thing function in a way that cannot be reduced to the sum of "objective" factors.

It is equally difficult to determine the nature of Ralahine's "success". We have seen many problems: institutional weaknesses, the anomalous position of Vandeleur, the financial burden, the question of legal status, the gender differences, the wage differentials, etc., and also how different social forces have different standards of assessment. Some of these problems were perceived problems at the time, others not. Some were remediable at the time; again, others were not. Ralahine itself is lost forever-all we have is a series of difficult-to-read traces. Something does resonate through the disparate sources. One senses that some very remarkable things did happen at Ralahine. In particular, there are still the echoes of a group of people working desperately hard to make a novel experiment work and functioning effectively for over two years. 